\title{
The Big Five Personality Traits, Occupational Stress, and Job Satisfaction
}

\author{
Andreas Petasis, Odysseas Economides
}

\begin{abstract}
The aim of this research was to examine the relationship between Big Five Personality traits (neuroticism, extraversion, openness to experience, agreeableness, conscientiousness), occupational stress and job satisfaction of police officers in Cyprus Police. A cross-sectional design was employed, where data was collected at a single time point. A total of 133 participants took part in the research program. The research instruments consisted of the Neo Five Factor Inventory (NEO-FFI) Police Stress Questionnaire (PSQ) and Job Satisfaction Survey (JSS). The result of the research indicated that the correlation of conscientiousness, extraversion, openness to experience and agreeableness to job satisfaction were not significantly linked while neuroticism had a moderately negative correlation with job satisfaction, and it was the only statistically significant relationship. Results showed that gender had a statistically significant relationship with job satisfaction, with males reporting greater job satisfaction than females. Further, work stress in the police force significantly predicts job satisfaction over and above the effect of personality traits.
\end{abstract}

Index Terms - Cyprus Police, job satisfaction, occupational stress, personality traits.

\section{INTRODUCTION}

Employee satisfaction or job satisfaction is one of the key goals of all Human Resource Management and Personnel Management since it contributes to ensuring the long-term efficiency and effectiveness of organizations in both public and private sector. A satisfied employee works as an ambassador for the company, is more loyal to the organization and its objectives, and takes pride in his job and achievements. Overall, job satisfaction is considered a very important part of an employee's lifecycle and a motivation to remain loyal and employed within an organization. On the other hand, dissatisfied workers experience lower productivity in the workplace, poorer performance, more job stress, and higher turnover rates. Moreover, low job satisfaction can result in low morale and low loyalty to the company itself [1]. Many researchers have been interested in factors associated with job satisfaction. Numerous factors that affect job satisfaction at both the organizational and individual levels have been identified so far [2]. Factors of job satisfaction identified at the organizational level include the compensation system, job characteristics, working conditions, leadership style, promotion opportunities and coworkers [3]. Factors identified at the individual level are matching personal interests and job, years of service and age, position in hierarchy, and overall life satisfaction.

As a global and multidimensional construct, job satisfaction has received considerable attention by researchers, predominantly focusing on employees in schools, companies and hospitals [4], [5]. Although the concept of job satisfaction has been extensively investigated in other professions, empirical research conducted on job satisfaction among police officers has been limited [6], [7], [8].

Police work is an area that needs further research regarding the job satisfaction and the impact of personality on job performance. The role of police officers is quintessential to the society as they maintain law and order, protect property and preserve the quality of life in the communities they serve. There are many challenges embedded in the work of police officers since they face pressure and stress due to several factors such as politics and interpersonal relations. On another level, the performance and job satisfaction can be affected not only by external factors such as long hours, workload, pay, poor communication with colleagues and managers and promotion chances but also by police officers' personality traits and individual qualities. Many researchers pointed to various factors that affect job satisfaction, among these factors the Big Five personality dimensions or the personality traits of employees which identified as important factors that form the employees' job satisfaction. Studies propose that the differences in the level of satisfaction amongst employees could be a consequence of employee's personality, since that some of personality traits and satisfaction was found to be strongly associated, whilst others found to be strongly associated with dissatisfaction [9], [10].

There are several reasons why job satisfaction is important to police organizations. First, negative attitudes toward work can adversely affect job performance in both the quantity and quality of services provided. Thus, poor performance can impact police-community relations by adversely affecting public attitudes toward the police [11]. In other words, job satisfaction in law enforcement is important because it promotes continuity of a professional and cohesive police force that works well together, follows proper policy and procedures, and provides the services needed to citizens [12].

Over the last decade Cyprus Police has undergone many changes, especially in the areas of goals, values, organization and infrastructure. The rate of crimes committed has significantly increased while new forms of crime have been developed. At the same time, budget constraints have led to limited human resources as recruitments were prohibited

Published on July 22, 2020

A. Petasis, American College, Cyprus.

(corresponding e-mail: andreas.petasis@ac.ac.cy)

O. Economides, American College, Cyprus.

(e-mail: odysseas.economides@ outlook.com) 
from 2011 until 2018 and to greater workload for the existing police officers that are also charged with providing their services to the community. During the same period, as part of austerity measures in the public sector, promotions were also abolished and additional measures such as budget cuts and salary reductions led to the deterioration of the financial position of the police service as an institution (in terms of both equipment and infrastructure) and its employees.

Policing is one of the foundational activities that allow civil society to exist. However, while it is an activity vital to any modern society, policing is a stressful occupation [13]. As a result of their job, police officers are exposed to stressful events more often than other workers. These high levels of occupational stress can result in stress-induced health problems for police officers [14], [15].

The aim of this study is to examine the factors that influence the job satisfaction of police officers in Cyprus Police. More specifically, whether personality traits correlate positively or negatively with job performance as well as which personality trait has more influence on job satisfaction than other traits are examined. Furthermore, this study examines whether occupational stress has an impact on job satisfaction. Therefore, the following research questions were developed:

RQ1: To what extent personality traits (Neuroticism, Extraversion, Openness to experience, Agreeableness, and Conscientiousness) predict the job satisfaction of police officers?

RQ2: Does occupational stress influence job satisfaction over and above personality traits?

\section{LITERATURE REVIEW}

According to the dispositional approach, job satisfaction is closely related to personality. It postulates that an individual has a strong predisposition towards a certain level of satisfaction, and that these remain fairly constant and stable across time [16]. The five-factor model has the advantage of being the most popular and widely investigated personality taxonomy, whose traits have proven their relevance to many criteria in organizational psychology, including job performance, leadership, and work motivation [17].

Many researchers believe that a correlation exists between personality characteristics and job satisfaction [16], [18]. Evidence exists about effects of personality on job satisfaction. In particular, the role of neuroticism and extraversion is important in job satisfaction among 395 diversely employed adults from a large metropolitan region in the Midwest [19]. The other three of the Big Five personality measurements have got less consideration and their impacts on job satisfaction are in general indistinct [20].

Meta-analyses have shown that personality traits are related to various occupational criteria including job performance, training proficiency, and job satisfaction [21], [22], [23]. It was found [21] that conscientiousness, extraversion, and openness to experience are related to performance criteria across occupational groups, that extraversion is related to job performance of salesmen and managers but not to job performance of professionals, policemen, and skilled workers, and that openness to experience is related to training proficiency.
In the past 15 years, research on the dispositional source of job satisfaction has progressed from a peripheral to a central area of inquiry in the job satisfaction literature. A metaanalysis of 163 samples was performed [10] suggesting that the five-factor model is a productive premise for investigating the natural source of job satisfaction. More specifically, it was concluded that continuous predictors of job satisfaction were Neuroticism and Extraversion and personality traits explained $17 \%$ variation in job satisfaction. Especially, the traits of Neuroticism, Extraversion, and Conscientiousness displayed a moderate relationship with job satisfaction. There was a negligible effect of openness to experience on job satisfaction. According to the same study, personality factors have most obvious connections to job satisfaction with extraversion having positive correlation with job satisfaction and neuroticism being negatively associated. The results of this research suggest that individuals with extraversion personality trait get more satisfaction with their job because it provides them with chances to experience excitement, while workers with introverted personality have less satisfaction.

Early meta-analytic work [21], [23] provided evidence suggesting that the Big Five might have some degree of utility for selecting employees into a variety of jobs. In both of these reviews, the researchers used studies that provided correlations between any type of personality variable and job performance, using the Big Five. Although their results were not altogether consistent, the general consensus drawn by researchers and practitioners was that personality does in fact hold some utility as a predictor of job performance. Subsequent meta-analyses [22], [24] solidified this status granted to personality, particularly regarding Conscientiousness. The results of a study [25] claimed Conscientiousness as one of the most valid predictors of performance for most jobs, second only to general intelligence.

Within police settings, several studies have been conducted to examine the correlation between personality traits and job satisfaction. A study on 235 sworn police officers in Lafayette, Louisiana Police Department found that neuroticism and extraversion were both significantly correlated to perceived levels of job satisfaction [26]. Another study [27] used a sample comprised of 1,535 police officers from a British police force. Personality traits were found to be directly related to work-related stress, coping strategies, tension and burn out as well as negatively related to overall job satisfaction. A study [28] investigated the correlation between personality traits and job satisfaction of 300 police officers in Punjab, Pakistan. Results found that there is a negative correlation between personality traits, neuroticism, openness to experience and job satisfaction, while extraversion, agreeableness and conscientiousness are positively correlated with job satisfaction.

In terms of occupational stress, [29] defined job stress as a psychological state perceived by individuals when faced with demands, constraints, and opportunities that have important but uncertain outcomes. Job stress is very much an individual reaction and differs from general stress as it is also organization, and job related [30]. Based on these definitions, job stress can produce adverse consequences for both the individual and the company since it has the effect of lowering 
motivation levels and performance, and increases turnover intentions [31]. Job stress was always seen as an unpleasant emotional situation that employees experience when the requirement of work-related or not related cannot be counter balanced with the ability to resolve them [32]. Companies spend a great deal of money to send their staff for stress management programs and trainings, since it is crucial to manage stress in order to increase job satisfaction and job performance. On the other hand, job stress boosts up the medical expenses, leads absenteeism and turnover to higher rates and contributes to poorer performance. Thus, it is not surprising that job stress is widely recognized as a significant business concern [33].

In developed and developing countries, occupational stress is a standout among the most significant workplace wellbeing hazard for workers [34]. He pointed out that there are different workplace components, called work stressors that make professions upsetting and difficult. Review of the literature, Research [35], [36] on the topic has indicated towards a number of factors acting as occupational stressors such as relationships and social interactions at work, career progression, work life balance and potential interruptions and organizational structure.

Numerous studies found that job stress influences the employees' job satisfaction and their overall performance in their work. According to [37] job satisfaction has been found significant relationship with job stress. The study of [38] and [39] showed that high levels of work stress are associated with low levels of job satisfaction. Several researchers have reported an inverse or negative relationship between perceived stress and job satisfaction; that is, as stress increases, job satisfaction decreases [40], [41], [42]. As indicated [40], job stress is one of the main sources of dissatisfaction of employees with their occupation. Occupational stress is in a direct negative connection with job satisfaction, as it depletes individual potential [43].

\section{RESEARCH METHOD}

A simple random population sample of research participants from different departments/services of Cyprus Police and from different cities of Cyprus was involved in this quantitative research in order to help the researcher in the generalization of results. Based on the nature of the study and the pursued researcher's objectives, three standardized validated questionnaires were selected in order to collect the primary data. Then statistical methods were used to test predetermined hypotheses regarding the relationship between variables. Data collected were analyzed using frequencies, percentages, tables and graphs.

A total of 164 participants were contacted to take part in the research program. Sample size was determined using $\mathrm{G}^{*}$ Power to identify the number of participants needed to achieve an estimated effect size of .2 , which is in line with previous studies in this area. $\mathrm{G}^{*}$ Power indicated a total of 81 participants necessary, suggesting that the sample obtained was more than satisfactory for the analysis required. Out of $164,133(81 \%)$ answered enough questions to be included in the analysis.

To measure the factors of this "Five-Factor Model," [44] constructed a questionnaire called the NEO Personality
Inventory (NEO-PI-R), which consists of 240 items that result in the five factors and a number of factor facets. Because of its length, a briefer version of the instrument, the NEO five factor inventory (NEO-FFI), was created [44] with 60 items, which was chosen for the purposes of this study.

The test instrument used for data collection for job satisfaction was Job Satisfaction Survey (JSS). The JSS was developed by [45] to fulfill the needs for human services to have an instrument to measure employee satisfaction. The design of the JSS is rooted in both public and private service organizations that may be either for-profit or non-profit in nature. The JSS assessed nine categories of job satisfaction: pay, promotion, supervision, fringe benefits, contingent rewards, operating conditions, coworkers, nature of work, and communication [45] and the survey had 36 comprehensive questions to assess the nine components.

The Organizational Police Stress Questionnaire was developed to measure specifically job stress of police officers and has been widely used in scholarly research on police stress. The Organizational Police Stress Questionnaire (PSQorg) not only measures police stress, but also psychometrically measures stressors associated with policing. To be precise, the Operational and Organizational Police Stress Questionnaires (PSQ op-org) are combined by two questionnaires: The (PSQ -op) which is related with work associated activities such as paper work, shift work, traumatic events and the (PSQ-org) which is associated to organizational stress factors such as behavior of supervisor, legislation obstacles, lack of training, lack of resources.

It is a 20-item measure to be rated on a 7-point Likert type scale ranging from 1 (No stress at all) to 7 (A lot of stress). This test has in total 40 questions (20 each questionnaire) and the minimum total score that may be achieved is 40 , while the maximum score that may be achieved is 280 . A high score demonstrated a high degree of work-related stress and low score demonstrated less work-related stress. These questionnaires were chosen as instruments to measure work stress because they are exclusively designed for police and apply to police work parameters and also that was previously have been widely used in scholarly research on police stress and there was no need to reevaluate this instrument.

Data was inputted into the SPSS software and inspected for missing values and outliers. Descriptive statistics were employed to check sample characteristics to provide variable mean and indicate any issues with skewness and kurtosis. Assumption for the normality of the parametric tests was also checked, but no problems were found. Following, data analysis addressed the study's hypotheses. Correlations between all variables were calculated and a hierarchical regression was employed. Job Satisfaction was entered as the depended variable, with demographic entered as control (Step 1) and personality traits (Step 2) and stress (Step 3) as predictors.

\section{RESUlTS AND DisCUSSION}

Females represented the majority of the surveyed respondents $(54,9 \%)$, though gender numbers were approximately equal. Ages were collected in groups to avoid any potential identification of specific participants. Most participants belonged in the $36-45$ age group (50,4\%), 
followed by $46-55$ year olds (32\%), then 26-35 year olds $(22,6 \%)$, over $55 \mathrm{~s}(2.3 \%)$, and last under $25 \mathrm{~s}(0.8 \%)$. Most of the participants held a college certificate $(22.6 \%)$, while $18.8 \%$ had a master's degree, $24 \%$ completed the police academy and $20 \%$ had completed a high school diploma. The majority of the officers reported being married (75.2\%), followed by $21 \%$ being single and only $9 \%$ being divorced. One hundred and five were constables, 15 sergeants, seven officers and five specialized staff. The most common range of income was 18,000 to $24,000(34.6 \%)$, followed by less than eighteen thousand (28.6\%), 24,001 to 30,000 (17, 3\%), 30,001 to $36,000(9 \%), 42,000$ to $52,000(6 \%)$ and only $3.8 \%$ reported earning more than 52,001. Regarding duties performed, 70 participants reported carrying out mainly office duties, 32 declared working mainly in an operational position, 23 reported doing in general duties and only seven reported carrying out mainly administration duties. In order to evaluate the study's hypotheses, first descriptive statistics including means, standard deviations for all study variables, including personality traits, police stress and job satisfaction were calculated. These are below:

TABLE 1: DESCRIPTIVE STATISTICS INCLUDING MEANS AND STANDARD DEVIATIONS AND RELIABILITY COEFFICIENTS For ALl STUDY VARIABLES

\begin{tabular}{|c|c|c|c|c|}
\hline Variable & Minimum & Maximum & $M$ & SD \\
\hline Personality Traits & & & & \\
\hline Agreeableness & 26.00 & 53.00 & 42.25 & 5.54 \\
\hline Extraversion & 27.00 & 57.00 & 41.91 & 5.51 \\
\hline Conscientiousness & 29.00 & 60.00 & 48.15 & 7.06 \\
\hline Openness-to- Exp & 12.00 & 49.00 & 35.53 & 5.83 \\
\hline Neuroticism & 15.00 & 51.00 & 32.86 & 6.95 \\
\hline Police Stress & 40.00 & 272.00 & 161.20 & 51.22 \\
\hline Job Satisfaction & 65.00 & 195.00 & 120.40 & 7.06 \\
\hline
\end{tabular}

As can be seen from the table, participants scored high on the first four personality traits; scoring on average 48.15 to 35.53 where scale mid-point is 36 . This indicates that participants were extraverted, conscientious, agreeable and open-to-experience. Moreover, they scored lower but not significantly different than mid-point on neuroticism $(\mathrm{M}=$ 32.86), indicating that on average they are more emotionally stable than neurotic. To be precise the highest score belongs to the conscientiousness with a mean of 48.18 , followed by agreeableness $\quad(\mathrm{M}=42.25), \quad$ openness-to-experience $(\mathrm{m}=35.53)$, and the lowest score belonging to neuroticism $(\mathrm{M}=32.86)$. For work stress, the score range of the test is between 40 and 280, with higher scores reflecting high stress and lower scores reflecting low job stress. The mean score was 161.20, which is higher than the scale mid-point of 140 , suggesting that officers have more than average stress at work. Moreover, some of the participants reported extremely high stress levels in the workplace, with scores around 195.00. In regard to job satisfaction huger scores in the Job Satisfaction Survey (JSS) reflect greater job satisfaction and the low score reflects lower job satisfaction. The mean score was 121.00 , which was close to the mid-point (Score $=108$, 00 ), indicating that officers had moderate job satisfaction. Moreover, some of the participants reported extremely negative attitudes towards satisfaction with extremely low score of 65.00(1= "strongly disagree"). Following descriptive statistics, correlations between all variables were calculated in order to investigate the relationship between personality traits, police stress and job satisfaction. The correlations are presented below in Table 2:

TABLE 2: INTER-CORRELATION MATRIX OF ALL THE STUDY VARIABLES

\begin{tabular}{|c|c|c|c|c|c|c|c|}
\hline & & & $(\mathrm{N}=1$ & & & & \\
\hline & 1 & 2 & 3 & 4 & 5 & 6 & 7 \\
\hline $\begin{array}{l}\text { Agreea- } \\
\text { bleness }\end{array}$ & - & $.45^{* *}$ & .26 & .02 & $-.02^{*}$ & -.28 & $.19^{*}$ \\
\hline $\begin{array}{l}\text { Conscie- } \\
\text { ntiousness }\end{array}$ & & - & $.39^{* *}$ & $.01^{* * *}$ & -.31 & -.13 & .06 \\
\hline Extra-version & & & - & -.13 & $-.34^{*}$ & -.04 & -.03 \\
\hline $\begin{array}{l}\text { Openness-to- } \\
\text { Experience }\end{array}$ & & & & - & -.00 & .05 & -.02 \\
\hline Neuroticism & & & & & - & .34 & -.33 \\
\hline Police Stress & & & & & & - & -.56 \\
\hline $\begin{array}{l}\text { Job } \\
\text { Satisfaction }\end{array}$ & & & & & & & - \\
\hline
\end{tabular}

The correlation for conscientiousness $(\mathrm{r}=.06)$, extraversion $(r=-.03)$, openness to experience $(r=-.02)$ to job satisfaction were negligible and thus, none were statistically significant at $\mathrm{p}=.05$. Also, agreeableness was positively associated with job satisfaction $(r=.19)$, but this association was also weak and thus was not significant at $\mathrm{p}=$ .05. This indicates that above four personality traits had no strong link to job satisfaction. However, neuroticism had a moderately negative correlation with job satisfaction, which was significant $(r=-.33, p<.05)$. This suggests that the less neurotic police officers were, the more satisfied they were with their job. In regards police stress, the correlation indicated that it was strongly and negatively associated with job satisfaction $(r=-.56)$. This indicates that greater police stress is associated with reduced satisfaction at work.

A three-stage hierarchical regression was then carried out to test the study's hypotheses of whether personality traits and job stress predict work satisfaction. The dependent variable was job satisfaction in the Cypriot police force. Demographics including age and gender of participants were used as control variables and were entered at step one of the hierarchical regressions. To investigate the hypotheses regarding personality traits, the five personality variables were entered at step two. Last, in order to test the hypothesis that work stress will explain variance in job satisfaction over and above personality traits, work stress was entered at step three. The hierarchical regression findings are shown in Table 3 below:

Looking at the regression analysis, it appears that at step one demographic variables contributed significantly to the regression model, $\mathrm{F}(2,127)=4.67, \mathrm{p}=.01$, accounting for $6.90 \%$ in variation. An examination of the beta coefficients demonstrated that only gender had a statistically significant relationship with job satisfaction $(\beta=-.18, p=.04)$, with males reporting greater job satisfaction than females. In the second step, introducing the five personality variables including extraversion, agreeableness, conscientiousness, openness to experience and neuroticism explained an additional $11.80 \%$ in variation $(18.60 \%$ total variation explained) and this change was again significant, $\mathrm{F}(5,122)=$ $3.53, \mathrm{p}=.01$. Therefore, this finding was in agreement with the study's hypotheses that personality traits significantly predict job satisfaction within the Cypriot police force. Examining the beta coefficients demonstrated that the only 
statistically significant relationship was between neuroticism and job satisfaction $(\beta=-.30, p<.01)$. Given the direction of the relationship, this indicates that neuroticism may play a negative role in job satisfaction, with more neurotic individuals, having less work satisfaction.

TABLE 3: HIERARCHICAL REGRESSION ANALYSIS, FOR VARIABLES PREDICTING ATTITUDES TOWARDS OUTCOME MONITORING $(\mathrm{N}=133)$

\begin{tabular}{|c|c|c|c|c|c|c|c|}
\hline & Predictors & $\boldsymbol{B}$ & $S E$ & $\beta$ & $t$ & $p$ & $\mathbf{R}$ \\
\hline \multirow[t]{3}{*}{$\begin{array}{l}\text { Step } \\
1 \\
\end{array}$} & & & & & & & 0.26 \\
\hline & Gender & -6.71 & 3.24 & -0.18 & -2.06 & 0.04 & \\
\hline & Age & 4.08 & 2.11 & 0.17 & 1.19 & 0.06 & \\
\hline \multirow[t]{8}{*}{$\begin{array}{l}\text { Step } \\
2\end{array}$} & & & & & & & 0.43 \\
\hline & Gender & -5.4 & 3.29 & -0.14 & -1.63 & 0.1 & \\
\hline & Age & 4 & 2.11 & 0.16 & 1.88 & 0.06 & \\
\hline & $\begin{array}{l}\text { Extraversi } \\
\text { on }\end{array}$ & -0.1 & 0.32 & -0.03 & -0.31 & 0.75 & \\
\hline & $\begin{array}{l}\text { Agreeable } \\
\text { ness }\end{array}$ & 0.54 & 0.32 & 0.16 & 1.67 & 0.1 & \\
\hline & $\begin{array}{l}\text { Conscienti } \\
\text { ousness }\end{array}$ & -0.29 & 0.27 & -0.1 & -1.05 & 0.29 & \\
\hline & $\begin{array}{l}\text { Neuroticis } \\
\mathrm{m}\end{array}$ & -0.82 & 0.25 & -0.3 & -3.25 & 0 & \\
\hline & $\begin{array}{l}\text { Openness- } \\
\text { to- } \\
\text { Experience }\end{array}$ & 0 & 0.27 & 0 & 0 & 1 & \\
\hline \multirow[t]{9}{*}{$\begin{array}{l}\text { Step } \\
3\end{array}$} & & & & & & & 0.62 \\
\hline & Gender & -3.17 & 2.89 & -0.09 & -1.09 & 0.28 & \\
\hline & Age & 4.26 & 1.84 & 0.17 & 2.3 & 0.02 & \\
\hline & $\begin{array}{l}\text { Extraversi } \\
\text { on }\end{array}$ & 0.08 & 0.28 & 0.02 & 0.26 & 0.8 & \\
\hline & $\begin{array}{l}\text { Agreeable } \\
\text { ness }\end{array}$ & 0.17 & 0.28 & 0.05 & 0.59 & 0.55 & \\
\hline & $\begin{array}{l}\text { Conscienti } \\
\text { ousness }\end{array}$ & -0.3 & 0.23 & -0.11 & -1.26 & 0.21 & \\
\hline & $\begin{array}{l}\text { Neuroticis } \\
\mathrm{m}\end{array}$ & -0.43 & 0.22 & -0.16 & -1.88 & 0.02 & \\
\hline & $\begin{array}{l}\text { Openness- } \\
\text { to- } \\
\text { Experience }\end{array}$ & 0.08 & 0.23 & 0.02 & 0.33 & 0.74 & \\
\hline & $\begin{array}{l}\text { Police } \\
\text { Stress }\end{array}$ & -0.18 & 0.02 & -0.49 & -6.3 & 0 & \\
\hline
\end{tabular}

Note: $\mathrm{B}=$ Unstandardized B, SE $=$ Coefficient Std. Error, $\beta=$ Standardised coefficient beta, $p=\operatorname{Sig} . R^{2}=R$ square, $D^{2}=R$ square change.

At the last step (Step 3), the addition of work stress explained an additional $20.10 \%$ of variation, with the final model explaining $38.70 \%$ total variation in job satisfaction. This change was again significant, $F(1,121)=39.70, p<.01$. An examination of the beta coefficients demonstrated that work stress had a highly significant relationship with job satisfaction $(\beta=-.49, \mathrm{p}<.01)$, with greater stress being associated with less job satisfaction. This supports the hypothesis that work stress in the police force significantly predicts job satisfaction over and above the effect of personality traits.

\section{CONCLUSIONS AND SugGestions}

The current research aimed to delve into the association between big five personality traits, job satisfaction and occupational stress among police officers serving in Cyprus Police in 2019. The outcomes of the existing research showed that personality traits significantly predict job satisfaction within the Cyprus Police Force. Furthermore, the research showed that occupational stress influences job satisfaction over and above personality traits.

Examining correlations between personality traits, police stress and job satisfaction found that neuroticism had a moderately negative correlation with job satisfaction, which was significant $(\mathrm{r}=-.33, \mathrm{p}<.05)$. Additionally, correlation results indicated that stress was strongly and negatively associated with job satisfaction $(\mathrm{r}=-.56)$. Furthermore, examining the beta coefficients, through Hierarchical regression analysis, it was demonstrated that the only trait that had statistically significant relationship with job satisfaction was neuroticism. This finding is in alignment with the theories which revealed that neuroticism was significantly associated with job satisfaction. Neuroticism in the research emerged as significant and negatively associated with satisfaction. One possible justification for such findings may be that the employees with high level of neuroticism are incapable of coping with conflicts and anxieties resulting in a lack of adjustment at workplace. A neurotic officer is not able to cope with stressful situations that officers usually have to face in the police work. The neurotic police officer shows emotional unbalanced behavior and he can't control his emotions in unfavorable situations and therefore he can't be satisfied with his job.

Regarding personality traits, one other main observation of the research was that conscientiousness had the highest mean score, with a mean of 48.18 where mid-point is 30 , and additionally had the highest positive correlation with job satisfaction, although not statistically significant. This positive correlation comes not as a surprise since it is in alignment with substantial amount of research that already exists which links conscientiousness with job satisfaction [21]. The person with high conscientiousness is more dutiful, organized, self-disciplined, responsible and accomplishes organizational goals better. Regarding the other traits agreeableness, extraversion, and openness to experience the research indicated that there is no strong link to job satisfaction and that a statistically significant relation to job satisfaction could not be proved. Although these traits would not be statistically proved in this research and they seem to affect less the job satisfaction than neuroticism, they should not be overlooked and ignored. In general, all traits are considered important and should be taken in consideration in order to maximize the Police officers' satisfaction and organizational productivity.

Also, according to the research only gender amongst the other demographic variables had a statistically significant relationship with job satisfaction, with males reporting greater job satisfaction than females. A possible justification for the greatest job satisfaction among male police officers is that that many duties address better to male officers (e.g. working at night, shift work, making arrests) and therefore these duties are more in alignment with the personality of male officers. Another reason may be that women generally are more sensitive, creative, demanding and more competitive and are harder to be satisfied. Cyprus police structure is still depending on male models and has not yet emphasized female entirely. Women still face discrimination in areas such as promotions. Although there are many qualified female officers, no female officer has ever been assigned to the post of Chief or Deputy Chief of Cyprus 
Police.

The most important conclusion of the research was that occupational stress influences job satisfaction over and above personality traits. According to the findings, job stress was the most important factor affecting job satisfaction. At step 3 of Hierarchical regression analysis, it was found that the addition of work stress explained an additional $20.10 \%$ of variation, with the final model explaining $38.70 \%$ of total variation in job satisfaction with this change being significant. An examination of the beta coefficients demonstrated that work stress had a highly significant relationship with job satisfaction $(\beta=-.49, \mathrm{p}<.01)$, with greater stress being associated with less job satisfaction.

This finding is in alignment with the statement of the problem in the introduction of the research where it was emphasized that the occupation of police officers is generally perceived as highly stressful, caught between the increasing threat of violence on the streets, increasing respond to homicides and shootings, incidents of sexual assault and domestic violence and other crimes, while there is high public demand and a mounting focus on police efficiency and probity. It is one of the few occupations where employees are asked continually to face physical dangers and to put their lives on the line at any time. The occupational stress is a common and important problem at the workplace since police officer job is heavily influenced by both internal and external factors. Departmental policies and procedures and organizational matters are some of the factors that causes stress to police officers. The financial crisis in Cyprus resulting in salary cuts, unpaid overtime duties, long hours of work, freezing of promotions and recruitments and increased obligations for the existing personnel, added more stress to Cyprus Police officers.

It is apparent from the results of the study that in order to improve work performance and satisfaction of the police officer, efforts must be made to lower the level of stress by putting into place practices and mechanisms. There are several helpful programs and measures to be considered when designing policies and procedures to eliminate police officer stress. The researchers recommend providing the police officers with positive and conducive work environment and provides officers with adequate resources such as technical equipment and infrastructure which are required to perform their duties. The study also recommends development and implementation of an employee assistance program that will assist police officers to cope with occupational stress. Training programs that equip officers with knowledge and skills on stress management, particularly for police officers who perform their duties in high risk work environments. Finally, the study recommended that personality test should be used in recruitment of police officers to fit the right person to the right job.

There are many factors that may have an influence on job satisfaction such as Socioeconomic status, working environment, promotions, safety and security, creativity in job, appreciation, hence a specialized study should be conducted for future reference in order to examine and analyze the factors that course stress among police officers in Cyprus Police as well as propose remedies to overcome these stressful situations.

\section{REFERENCES}

[1] C. Javed and K. Sirajul., "Employees' job satisfaction: analysing the satisfaction by length of service and employment status", International Journal of Management Studies and Business Research, vol. 3(2), pp. 16-24, 2014.

[2] F. Luthans, Organizational behaviour, 10th ed., McGraw-Hill, 2005.

[3] P.C. Smith, L. Kendall and C.L. Hulin, The measurement of satisfaction in work and retirement: A strategy for the study of attitudes, Chicago. IL: Rand McNally, 1969.

[4] H. Lu, X. Zhang and A. While, "Job satisfaction among hospital nurses revisited: A systematic review", International Journal of Nursing Studies, vol. 49(8), pp. 1017-1038, 2012.

[5] M. Zembylas and E. Papanastasiou, "Job satisfaction among schoolteachers in Cyprus", Journal of Educational Administration, vol. 42(3), pp. 357-374, 2004.

[6] R. Bennett, "Job satisfaction among police constables: A comparative study in three developing nations", Justice Quarterly, vol. 14, pp. 295323, 1997.

[7] M.L. Dantzker and M.A. Surrette, "The perceived levels of job satisfaction among police officers: A descriptive review", Journal of Police and Criminal Psychology, vol. 11(2), pp. 7-12, 1994.

[8] J. Zhao, Q. Thurman and N. He, "Sources of job satisfaction among police officers: A test of demographic and work environment models", Justice Quarterly, vol. 16, pp. 153-172, 1999.

[9] A. Furnham, K. Petrides and S. Spencer-Bowdage, "The Effects of Different Types of Social Desirability on the Identification of Repressors", Journal of Psychology, vol. 33, pp. 119-130, 2002.

[10] T.A. Judge, D. Heller and M.K. Mount, "Five-factor model of personality and job satisfaction: A meta-analysis", Journal of Applied Psychology, vol. 87(3), pp. 530-541, 2002.

[11] A. Buzawa, T. Austin and J. Bannon, "The role of selected sociodemographic and job specific variables in predicting patrol officer job satisfaction: A re-examination ten years later", American Journal of Police, vol. 13(2), pp. 51-75, 1994.

[12] J.M. Sharp, Job Satisfaction in Law Enforcement Officers according to Generational Cohorts. Walden Dissertations and Doctoral Studies, 2016.

[13] J. Shane, "Organizational Stressors and Police Performance", Journal of Criminal Justice, vol. 38(4), pp. 807-818, 2010.

[14] P. Lagestad and A. Van den Tillaar, "A comparison of training and physical performance of police students at the start and the end of three-year police education", The Journal of Strength and Conditioning Research, vol. 28(5), pp. 1394-1400, 2014.

[15] C. Randall and N. Buys, "Managing occupational stress injury in police services: A literature review", International Public Health Journal, vol. 5, pp. 413-425, 2013.

[16] T.A. Judge, E.A. Locke and C.C. Durham, "The dispositional causes of job satisfaction: A core evaluations approach", Research in Organizational Behaviour, vol. 19, pp. 151-188, 1997.

[17] T.A. Judge, D. Heller and R. Klinger, "The Dispositional Sources of Job Satisfaction: A Comparative Test", Applied Psychology, vol. 57(3), pp. 361-372, 2008.

[18] R. Hoppock, Job satisfaction, New York. NY: Harper \& Row Publishing, 1935.

[19] D.M. Tokar and L.M. Subich, "Relative contributions of congruence and personality dimensions to job satisfaction", Journal of vocational behaviour, vol. 50, pp. 482-491, 1997.

[20] D.M. Tokar, A.R. Fischer and L.M. Subich, "Personality and vocational behaviour: A selective review of the literature", Journal of Vocational Behaviour, vol. 53(2), pp. 115-153, 1998.

[21] M.R. Barrick and M.K. Mount, "The Big Five personality dimensions and job performance: a meta-analysis", Personnel Psychology, vol. 44, pp. 1-26, 1991.

[22] J.F. Salgado, "The five-factor model of personality and job performance in the European community", Journal of Applied Psychology, vol. 82, pp. 30-41, 1997.

[23] R.P. Tett, D.N. Jackson and M. Rothstein, "Personality measures as predictors of job performance: a meta-analytic review", Personnel Psychology, vol. 44(4), pp. 703-742, 1991.

[24] D.W. Organ and A. Lingl, "Personality, satisfaction, and organizational citizenship behaviour", Journal of Social Psychology, vol. 135, pp. 339-350, 1995.

[25] O. Behling, "Employee Selection: Will Intelligence and Conscientiousness Do the Job?", The Academy of Management Executive (1993-2005)", vol. 12(1), pp. 77-86, 1988.

[26] S.M. Mire, "Correlates of job satisfaction among police officers". Doctoral Dissertation, Sam Houston State University, 2005. 
[27] A. Ortega, S.O. Brenner and P. Leather, "Occupational stress, coping and personality in the police: An SEM study", International Journal of Police Science and Management, vol. 9(1), pp. 36-50, 2007.

[28] U. Khizar, D. Orcullo and J. Mustafa, "The impact of personality traits and gender on job satisfaction of police officers in Punjab, Pakistan", International Journal of Advanced Research, vol. 4(6), pp. 13911396, 2016

[29] J.K., Sager, "Type A Behaviour Pattern (TABP) Among Salespeople and its Relationship to Job Stress", Journal of Personal Selling and Sales Management, vol. 11(2), pp. 1-14, 1991.

[30] J. Chen and C. Silverthorne, "The impact of locus of control on job stress, job performance and job satisfaction in Taiwan", Leadership \& Organization Development Journal, vol. 29(7), pp. 572-582, 2008

[31] D.C. Montgomery, G. Blodgett and J.H. Barnes, "A model of financial securities salespersons job stress", Journal of Services Marketing, vol. 10(3), pp. 21-38, 1996.

[32] G. Halkos and D. Bousinakis, "The effect of stress and satisfaction on productivity", International Journal of Productivity and Performance Management, vol. 59(5), pp. 415-443, 2010.

[33] O. Siu, "Job stress and job performance among employees in Hong Kong”, International Journal of Psychology, vol. 38(6), pp. 337-347, 2003.

[34] S. Paul, "Cross national differences in relationships of work demands, job satisfaction, and turnover intentions with work family conflict", Personnel Psychology, vol. 11(4), pp. 133-136, 2002.

[35] K. Chang and L. Lu, "Characteristics of Organizational Culture Stressors and Wellbeing", Journal of Management Psychology, vol. 22(6), pp. 549-568, 2007.

[36] C.L. Cooper and J. Marshall, "Occupational sources of stress: a review of the literature relating to CHD and mental ill-health", Journal of Occupational Psychology, vol. 49, pp. 11-28, 1976.

[37] P.L. Stamps and E.B. Piedmonte, "Nurses and Work Satisfaction: an index for measurement", Health Administration Press, 1986.

[38] P.A. Landsbergis, "Occupational stress among health care workers: A test of the job demands-control mode", Journal of Organizational behaviour, vol. 9(3), pp. 217-239, 1998.

[39] D. Terry, M. Nielsen and L. Perchard, "Effects of work stress on psychological well-being and job satisfaction: The stress buffering role of social support", Australian Journal of Psychology, vol. 45(3), pp.168-175, 1992.

[40] N.A. Flanagan and T.J. Flanagan, "An analysis of the relationship between job satisfaction and job stress in correctional nurses", Research in Nursing and Health, vol. 25(4), pp. 282-294, 2002.

[41] H. Sveinsdottir, P. Biering and A. Ramel, "Occupational Stress, Job Satisfaction, and Working Environment among Icelandic Nurses: A Cross-Sectional Questionnaire Survey", International Journal of Nursing Studies, vol. 43, pp. 875-889, 2006.

[42] G.A. Zangaro and K.L. Soeken, "A Meta-Analysis of studies of nurses' job satisfaction", Research in Nursing and Health, vol. 30, pp. 445-458, 2007.

[43] N. Yahaya, A. Yahaya, F.A. Tamyes, J. Ismail and S. Saini Jaalam, "The effect of various modes of occupational stress, job satisfaction, intention", Journal of Social Sciences, vol. 5(4), pp. 390-397, 2010.

[44] Costa, P. T., Jr., \& McCrae, R. R., Revised NEO Personality Inventory (NEO- PI-R) and NEO Five-Factor Inventory (NEO-FFI) professional manual, Odessa, FL: Psychological Assessment Resources, 1992.

[45] P. E. Spector, Job satisfaction: Application, assessment, causes, and consequences, Thousand Oaks, CA: Sage Publications, 1997. 